\title{
PENGENDALIAN INFLASI, MONETER, DAN FISKAL DALAM PERSPEKTIF EKONOMI MAKRO ISLAM
}

\author{
Triwahyuni \\ Institut Agama Islam Agus Salim, Metro Lampung, Email: Triwahyuni579@yahoo.com
}

\begin{abstract}
The economic development of a country, including in Indonesia, cannot be separated from the monetary and fiscal policies adopted by each country concerned. However, the monetary and fiscal policies adopted by each country vary depending on the real economic conditions, the direction and development objectives to be achieved. In principle, the management of monetary and fiscal policies aims to maintain the inflation rate by regulating the circulation of money and interest rates which tend to increase in society. The purpose of this research is to find out how the government controls inflation, monetary and fiscal, and their impact on the economy from an Islamic macroeconomic perspective. The method used is library research method and the data used is secondary data which is in accordance with a number of relevant literature. As an effort to overcome inflation, monetary and fiscal policies, the government needs to carry out macroeconomic policies in relation to achieving the inflation target and economic growth. Thus, every country needs to maintain economic stability in accordance with the challenges it faces.
\end{abstract}

Keywords: Control, Inflation, Monetary, Fiscal, Islamic Macroeconomics

\begin{abstract}
Abstrak
Perkembangan ekonomi suatu negara, termasuk pula di Indonesia tentu tidak terlepas dari kebijakan moneter dan fiskal yang ditempuh oleh setiap negara yang bersangkutan. Tetapi kebijakan moneter dan fiskal yang ditempuh berbeda-beda oleh setiap negara bergantung kepada kondisi ekonomi riil, arah, dan tujuan pembangunan yang hendak dicapai. Pengelolaan kebijakanmoneter dan fiskal pada prinsipnya bertujuan untuk menjaga tingkat inflasi dengan cara mengatur peredaran uang dan suku bunga yang cenderung semakin bertambah di masyarakat. Tujuan dari penelitian ini adalah untuk mengetahui bagaimana pemerintah mengendalikan inflasi, moneter, dan fiskal, serta dampaknya terhadap perekonomian dalam perspektif ekonomi makro Islam. Metode yang dipergunakan menggunakan metode library research serta data yang dipergunakan yaitu data sekunder yang sesuai dengan sejumlah literatur yang relevan. Sebagai upaya untuk mengatasi inflasi, kebijakan moneter dan fiskal, pemerintah perlu melakukan kebijakan ekonomi makro dalam kaitannya dengan pencapaian target inflasi dan pertumbuhan ekonomi. Dengan demikian setiap negara perlu menjaga stabilitas ekonomi sesuai dengan tantangan yang dihadapinya.
\end{abstract}

Kata Kunci: Pengendalian, Inflasi, Moneter, Fiskal, Ekonomi Makro Islam. 
200 | Triwahyuni, Pengendalian Inflasi, Moneter dan Fiskal dalam Perspektif Ekonomi Makro Islam DASAR PEMIKIRAN

Tingkat harga merupakan salah satu indikator yang sangat penting dalam sistem perekonomian modern, karena bisa menjaga keseimbangan alokasi sumber daya ekonomi dalam suatu negara. Dengan adanya tingkat inflasi yang tinggi dapat mengaburkan bahkan menghilangkan indikator tersebut dan mendistorsi harga-harga yang terjadi. Hal ini akan menyulitkan suatu perencanaan dan tidak memotivasi masyarakat dan juga dunia usaha untuk melakukan tabungan dan investasi. Peningkatan kesejahteraan masyarakat secara adil dan merata pada hakikatnya merupakan tujuan dari pembangunan ekonomi. Pendapatan per kapita merupakan salah satu tolok ukur tingkat kesejahteraan masyarakat, karena mampu menggambarkan secara riil terhadap keberhasilan pembangunan ekonomi dan tingkat kemakmuran masyarakat. Parameter untuk mengukur tingkat kemakmuran dan pertumbuhan ekonomi suatu negara juga bisa dilihat dari adanya sumber daya manusia yang berkualitas.

Dalam suatu sistem perekonomian modern target atau sasaran inflasi merupakan tingkat inflasi yang harus dicapai oleh Bank Indonesia, berkoordinasi dengan Pemerintah. Penetapan sasaran inflasi berdasarkan Undang-Undang Nomor 23 Tahun 1999 Tentang Bank Indonesia dilakukan oleh pemerintah. Dalam Nota Kesepahaman antara Pemerintah dan Bank Indonesia, sasaran inflasi ditetapkan untuk tiga tahun ke depan melalui Peraturan Menteri Keuangan (PMK). Berdasarkan Peraturan Menteri Keuangan Nomor: 124/PMK.010/ 2017 tentang Sasaran Inflasi 2019-2021 yang ditetapkan masing-masing sebesar 3,5\%, 3,0\% dan 3,0\%, dengan deviasi masing-masing $\pm 1 \%$ (BI, 2019).

Sementara inflasi juga dapat dipengaruhi oleh faktor yang berasal dari sisi penawaran ataupun yang bersifat kejutan (shocks) seperti halnya kenaikan harga minyak dunia dan adanya gangguan panen atau banjir. Dilihat dari segi bobot dalam keranjang IHK, bobot inflasi yang dipengaruhi oleh faktor kejutan diwakili oleh kelompok volatile food dan administered prices yang mencakup kurang lebih $40 \%$ dari bobot IHK. Pengendalian inflasi sangat penting menjadi salah satu perhatian pemerintah karena beberapa alasan. Inflasi bisa memperburuk distribusi pendapatan yaitu menjadi tidak seimbang, menyebabkan berkurangnya tabungan domestik yang merupakan sumber dana investasi bagi negara-negara berkembang. Dengan terjadinya inflasi juga bisa mengakibatkan deficitnya neraca perdagangan serta menigkatnya utang luar negeri. 
Ekonomica Sharia: Jurnal Pemikiran dan Pengembangan Ekonomi Syariah Volume 6 Nomor 2 Edisi Februari $2021 \mid 201$

Salah satu kebijakan yang efektif untuk mengatasi kondisi ekonomi yang tidak stabil pada suatu negara adalah melalui kebijakan fiskal. Stabilitas ekonomi suatu negara diantaranya tercermin dari stabilitas harga, dalam arti tidak terdapatnya gejolak harga yang besar yang dapat merugikan masyarakat, baik konsumen maupun produsen yang akan merusak sendi-sendi perekonomian. Kenaikan harga-harga yang menjadi penyebab terjadinya inflasi dapat diklasifikasikan dan jika harga-harga naik secara perlahan-lahan maka inflasi yang terjadi disebut sebagai "Creeping Inflation". Jika harga-harga meningkatnya secara cepat maka kondisi tersebut disebut sebagai "Hyperinflation" atau inflasi yang melebihi 50 persen per bulan atau lebih dari 1 persen per hari (Mankiw, 2003). Pengedalian inflasi dengan menggunakan beberapa instrumen kebijakan yang tepat akan membawa akibat stabilitas perekonomian makro yang baik. Sehingga terciptanya kemakmuran dan kesejahteraan masyarakat banyak serta keadilan ekonomi dan sosial bisa terwujud. Permasalahan yang akan dikaji lebih lanjut adalah bagaimana mengendalikan inflasi, moneter dan fiskal serta dampaknya terhadap perekonomian dalam perspektif ekonomi makro Islam?

\section{METODE}

Tulisan ini menggunakan metode deskriptif-analitis dan pendekatan kualitatif. Metode dan pendekatan tersebut digunakan untuk menjelaskan kajian kepustakaan tentang pengendalian inflasi, moneter dan fiskal serta dampaknya terhadap perekonomian dalam perspektif ekonomi makro Islam. Sumber dan teknik pengumpulan data diperoleh dari studi kepustakaan dan sumber literatur lainnya yang relevan dengan obyek yang diteliti. Teknik analisis data dilakukan secara deduktif dan induktif untuk menemukan rumusan konseptual tentang pengendalian inflasi, moneter dan fiskal serta dampaknya terhadap perekonomian dalam perspektif ekonomi makro Islam. Melalui hasil penelitian ini diharapkan memperoleh kesimpulan akhir untuk memperkuat dan mengembangkan hasil-hasil penelitian sebelumnya yang relevan. 


\section{PEMBAHASAN}

\section{Pengendalian Inflasi dalam Perspektif Ekonomi Makro}

Bank Indonesia dan Pemerintah senantiasa berkomitmen untuk mencapai sasaran inflasi yang sudah ditetapkan melalui koordinasi kebijakan yang konsisten dengan sasaran inflasi tersebut. Salah satu upaya pengendalian inflasi menuju inflasi yang rendah dan stabil adalah dengan membentuk dan mengarahkan ekspektasi inflasi masyarakat agar mengacu (anchor) pada sasaran inflasi yang telah ditetapkan. Sebelum Undang-Undang Nomor 23 Tahun 1999 tentang Bank Indonesia, sasaran inflasi ditetapkan oleh Bank Indonesia. Sementara setelah UU tersebut, dalam rangka meningkatkan kredibilitas Bank Indonesia maka sasaran inflasi ditetapkan oleh pemerintah. Kebijakan moneter Bank Indonesia ditujukan untuk mengelola tekanan harga yang berasal dari sisi permintaan aggregat (demand management) relatif terhadap kondisi sisi penawaran. Dalam hal ini kebijakan moneter tidak ditujukan untuk merespon kenaikan inflasi yang disebabkan oleh faktor yang bersifat kejutan yang bersifat sementara yang akan hilang dengan sendirinya seiring dengan berjalannya waktu.

Menurut Gregory Mankiw (2003), salah satu penyebab inflasi adalah terjadinya partumbuhan kuantitas uang yang beredar di masyarakat, apabila pemerintah mencetak dan/atau mengedarkan uang terlalu banyak maka nilai uang tersebut akan merosot. Secara sederhana inflasi diartikan sebagai suatu kecenderungan meningkatnya hargaharga barang dan jasa secara umum dan terus menerus. Terdapat dua kata kunci yang terkandung dalam pengertian inflasi tersebut yaitu pertama kenaikan harga secara umum dan kedua secara terus menerus. Dalam inflasi harus terkadung adanya unsur kenaikan harga secara umum (Suseno, 2009). Pada prinsipnya inflasi ialah suatu proses meningkatnya harga-harga secara umum dan terus menerus yang berkaitan dengan mekanisme pasar yang dapat disebabkan oleh berbagai faktor, diantaranya konsumsi masyarakat yang meningkat, berlebihnya likuiditas di pasar yang memicu konsumsi atau bahkan spekulasi, dan akibat adanya ketidak lancaran distribusi barang (Astiyah, 2009).

Kenaikan harga dari satu atau dua barang saja tidak dapat disebut sebagai inflasi kecuali bila kenaikan itu meluas (atau mengakibatkan kenaikan harga) pada barang lainnya. Indikator yang sering digunakan untuk mengukur tingkat inflasi adalah Indeks 
Harga Konsumen (IHK). Perubahan IHK dari waktu ke waktu menunjukkan pergerakan harga dari paket barang dan jasa yang dikonsumsi masyarakat. Penentuan barang dan jasa dalam keranjang IHK dilakukan atas dasar Survei Biaya Hidup (SBH) yang dilaksanakan oleh Badan Pusat Statistik (BPS). Kemudian, BPS akan memonitor perkembangan harga dari barang dan jasa tersebut secara bulanan di beberapa kota, pasar tradisional dan modern pada beberapa jenis barang atau jasa di setiap kota.

Bicara soal inflasi mau tidak mau harus melihatnya terhadap bentuk dari inflasi itu sendiri yaitu inflasi merayap dan inflasi yang terus menerus berkelanjutan dan dianggap serius apabila melewati batas $5 \%$, serta bagaimana cara pemerintah untuk mengatasi inflasi jenis ini. Zero inflation atau inflasi pada nol persen menjadi harapan dan tujuan dari pemerintah dalam mengatasi system perekonomian nasional sangat sulit untuk bisa terwujud. Untuk menjaga stabilitas nasional di bidang ekonomi maka pemerintah perlu untuk menjaga tingkat inflasi jangan sampai melebihi $5 \%$. Salah satu upaya dari pemerintah guna mengatasi masalah inflasi ini adalah dengan melakukan kebijakan fiskal dan kebijakan moneter. Kebijakan fiskal dengan cara pengurangan pengeluaran pemerintah yang dilaksanakan oleh kementrian keuangan sedangkan kebijakan moneter dilakukan oleh Bank Indonesia.

\section{Pengendalian Moneter dan Fiskal dalam Ekonomi Makro}

Pelaksanaan kebijakan fiskal dan kebijakan moneter yang dilakukan oleh dua istitusi yang berbeda ini tidak boleh bertentangan antara yang satu dengan yang lainnya, dimana keduanya haruslah saling menyesuaikan kebijakan yang dibuatnya. Salah satu tindakan yang harus diambil oleh Bank Indonesia dalam mengatasi masalah inflasi ini yaitu dengan cara mengurangi penawaran uang dan menaikkan suku bunga, di mana kebijakan moneter ini akan mengurangi investasi dan pengeluaran rumah tangga. Sedangkan kebijakan yang dilakukan oleh kementrian keuangan dalam bentuk kebijakan fiskal yaitu dengan cara mengurangi pengeluaran dan menaikkan pajak individu dan perusahaan. Kedua langkah ini dapat mengurangi pengeluaran pemerintah, mengurangi investasi dan mengurangi pengeluaran rumah tangga (Sukirno, 2016).

Sebagai upaya untuk mengatasi inflasi maka salah satu kebijakan moneter yang diambil oleh Bank Indonesia adalah dengan dengan mengimplementasikan suku bunga 
acuan atau suku bunga kebijakan baru yang menggantikan BI Rate dan diberi nama BI 7-Day (reverse) Repo Rate, yang mulai berlaku efektif sejak 19 Agustus 2016. Penguatan kerangka operasi moneter ini merupakan hal yang lazim dilakukan di berbagai bank sentral dan merupakan best practice internasional dalam pelaksanaan operasi moneter. Kerangka operasi moneter senantiasa disempurnakan untuk memperkuat efektivitas kebijakan dalam upaya mencapai sasaran inflasi yang ditetapkan.

Instrumen BI 7-Day (reverse) Repo Rate dapat secara cepat memengaruhi pasar uang, perbankan dan sektor riil, karena instrumen BI 7-Day Repo Rate sebagai acuan yang baru memiliki hubungan yang lebih kuat ke suku bunga pasar uang, sifatnya transaksional atau diperdagangkan di pasar dan mendorong pendalaman pasar keuangan, khususnya penggunaan instrumen repo. Sesuai dengan prinsip implementasi reformulasi, perubahan tersebut tidak mengubah arah kebijakan moneter karena kedua suku bunga kebijakan BI Rate dan BI 7-Day Repo Rate berada dalam satu struktur suku bunga (term structure) yang sama dalam mengarahkan inflasi agar sesuai dengan sasarannya. Perbedaan hanya terlihat pada tenor instrumen, yakni BI Rate setara dengan instrumen moneter 12 bulan, sedangkan BI 7-Day Repo Rate setara dengan instrumen moneter 7 hari (BI, 2019).

Paling tidak ada tiga dampak utama yang diharapkan dengan dipergunakannya instrumen BI 7-day (reverse) Repo Rate sebagai suku bunga kebijakan baru yaitu (BI, 2019):

a. Menguatnya sinyal kebijakan moneter dengan suku bunga (Reverse) Repo Rate hari sebagai acuan utama di pasar keuangan;

b. Meningkatnya efektivitas transmisi kebijakan moneter melalui pengaruhnya pada pergerakan suku bunga pasar uang dan suku bunga perbankan;

c. Terbentuknya pasar keuangan yang lebih dalam, khususnya transaksi dan pembentukan struktur suku bunga di pasar uang antarbank (PUAB) untuk tenor 3 bulan sampai 12 bulan.

Kemampuan Bank Indonesia untuk mengendalikan inflasi sangat terbatas apabila terdapat kejutan (shocks) yang sangat besar seperti ketika terjadi kenaikan harga BBM di tahun 2005 dan 2008 sehingga menyebabkan adanya lonjakan inflasi. Dengan pertimbangan 
bahwa laju inflasi juga dipengaruhi oleh faktor yang bersifat kejutan tersebut maka pencapaian sasaran inflasi memerlukan kerjasama dan koordinasi antara pemerintah dan BI melalui kebijakan makroekonomi yang terintegrasi baik dari kebijakan fiskal, moneter maupun sektoral. Lebih jauh, karakteristik inflasi Indonesia yang cukup rentan terhadap kejutan-kejutan (shocks) dari sisi penawaran memerlukan kebijakan-kebijakan khusus untuk permasalahan tersebut.

Salah satu kebijakan yang diambil oleh bank sentral atau otoritas moneter untuk menjaga stabilitas ekonomi makro melalui kebijakan moneter. Kebijakan moneter ditujukan agar likuiditas dalam perekonomian berada dalam jumlah yang tepat sehingga dapat melancarkan transaksi perdagangan tanpa menimbulkan tekanan inflasi. Beberapa indikator yang biasanya digunakan dalam perekonomian untuk menilai kebijakan moneter antara lain jumlah uang beredar (money supply), inflasi, tingkat suku bunga, nilai tukar dan ekspektasi masyarakat. Suku bunga dapat berpengaruh terhadap investasi sektor industri yang akan mendorong produksi. Sedangkan nilai tukar berpengaruh terhadap harga yang meliputi produk dan input produksi. Suku bunga dan nilai tukar merupakan instrumen kebijakan moneter yang sangat memengaruhi perdagangan produk industri baik domestik maupun internasional. Jika yang dilakukan adalah meningkatkan money supply, maka pemerintah dikatakan menempuh kebijakan moneter ekspansif. Sebaliknya jika money supply dikurangi, pemerintah menempuh kebijakan moneter kontraktif (Budiyanti, 2014).

Dalam kebijakan moneter yang diambil oleh pemerintah sekarang ini apabila dilihat dari sektor ekonomi Islam, tidak ada satupun instrumen kebijakan moneter yang pernah dipergunakan diawal periode keislaman, karena belum adanya sistem perbankan seperti yang sekarang (Aravik, 2017). Instrument lainnya yang sekarang ini dipergunakan adalah dengan melakukan operasi pasar terbuka di antaranya melalui jual beli surat berharga. Operasi pasar terbuka inipun tidak ada dalam sejarah perekonomian Islam pada awal perkembangannya. Sedangkan sistem yang telah diterapkan oleh pemerintah menyangkut konsumsi, tabungan, investasi dan perdagangan telah menciptakan instrumen secara otomatis untuk pelaksanaan kebijaksanaan moneter (Karim, 2004). 


\section{Triwahyuni, Pengendalian Inflasi, Moneter dan Fiskal dalam Perspektif Ekonomi Makro Islam}

Dalam teori makro ekonomi kebijakan fiskal adalah suatu kebijakan ekonomi dalam rangka mengarahkan kondisi perekonomian untuk menjadi lebih baik dengan jalan mengubah penerimaan dan pengeluaran negara. Instrumen penting dalam kebijakan fiskal adalah penerimaan dan pengeluaran negara. Pemerintah merancang porsi yang pas antara penerimaan dan pengeluaran untuk mencapai kestabilan ekonomi. Diantara beberapa pilihan instrumen kebijakan fiskal yang lazim dilakukan pemerintah dalam menjaga stabilitas ekonomi makro antara lain:

a) Menaikkan atau menurunkan pajak rumah tangga;

b) Mengatur pengeluaran pemerintah untuk pengusaha tertentu;

c) Memberikan rangsangan fiskal (insentif atau subsidi) pada pengusaha tertentu.

Dalam arah kebijakan bidang moneter Bank Indonesia memiliki tujuan untuk mencapai dan memelihara kestabilan nilai rupiah. Tujuan tersebut sebagaimana tercantum dalam Pasal 7 Undang-Undang Nomor 23 Tahun 1999 tentang Bank Indonesia, yang telah diamandemen oleh Undang-Undang Nomor 3 Tahun 2004 dan amandemen terahir melalui UndangUndang Nomor 6 Tahun 2009. Terdapat dua dimensi mengenai kestabilan nilai rupiah, yaitu pertama kestabilan nilai rupiah adalah kestabilan terhadap harga-harga barang dan jasa yang tercermin dari perkembangan laju inflasi. Sementara itu, dimensi kedua terkait dengan perkembangan nilai tukar rupiah terhadap mata uang negara lain. Dalam konteks perkembangan nilai rupiah terhadap mata uang negara lain, Indonesia menganut sistem nilai tukar mengambang (free floating).

Peran kestabilan nilai tukar sangat penting dalam mencapai stabilitas harga dan sistem keuangan. Oleh karena itu, Bank Indonesia juga menjalankan kebijakan untuk menjaga kestabilan nilai tukar agar sesuai dengan nilai fundamentalnya dengan tetap menjaga bekerjanya mekanisme pasar. Dalam upaya mencapai tujuan rersebut, Bank Indonesia sejak 1 Juli 2005 menerapkan kerangka kebijakan moneter Inflation Targeting Framework (ITF). Kerangka kebijakan tersebut dipandang sesuai dengan mandat dan aspek kelembagaan yang diamanatkan oleh Undang-Undang. Dalam kerangka ini, inflasi merupakan sasaran yang diutamakan (overriding objective). Bank Indonesia secara konsisten terus-menerus melakukan berbagai penyempurnaan kerangka kebijakan moneter, sesuai dengan perubahan dinamika dan tantangan perekonomian yang terjadi, guna memperkuat efektivitasnya (BI, 2019). 
Dalam konteks ekonomi makro, fundamental ekonomi penting lainnya adalah kebijakan fiskal pemerintah. Menurut Saragih (2016), kebijakan fiskal merupakan bagian dari kebijakan makro ekonomi mempunyai bertujuan mencapai berbagai sasaran pembangunan di berbagai sektor dan memiliki tiga fungsi utama, yaitu:

a. Fungsi alokasi anggaran negara bertujuan untuk mendanai pembangunan di berbagai bidang;

b. Fungsi distribusi pendapatan dan subsidi yang mempunyai tujuan untuk meningkatkan kesejahteraan masyarakat;

c. Fungsi stabilisasi ekonomi-makro, bertujuan untuk mendorong pertumbuhan ekonomi yaitu melalui upaya meredam siklus-bisnis atau fluktuasi ekonomi atau yang bersifat kontra siklis (counter cyclical) bahwa dalam kondisi perekonomian lesu, pengeluaran pemerintah yang bersifat autonomous, termasuk belanja barang dan/atau jasa serta belanja modal dapat memberi stimulus terhadap perekonomian untuk tumbuh tinggi.

Sasaran operasional kebijakan moneter dicerminkan pada perkembangan suku bunga Pasar Uang Antar Bank Overnight (PUAB O/N). Pergerakan di suku bunga PUAB ini diharapkan akan diikuti oleh perkembangan di suku bunga deposito hingga pada gilirannya suku bunga kredit perbankan. Dengan mempertimbangkan faktor-faktor dalam perekonomian Bank Indonesia pada umumnya akan menaikkan acuan tingkat suku bunga apabila inflasi kedepan diperkirakan melampaui sasaran yang telah ditetapkan, sebaliknya Bank Indonesia akan menurunkan acuan tingkat suku bunga, apabila inflasi kedepan diperkirakan dibawah sasaran yang telah ditetapkan (Saridawati, 2015).

Pelaksanaan kebijakan moneter yang dilakukan otoritas moneter sebagai pemegang kendali money supply untuk mencapai tujuan kebijakan moneter dilakukan dengan menetapkan target yang akan dicapai dan dengan instrument apa target tersebut akan dicapai. Mahmud (2009) menjelaskan bahwa instrument-instrumen pokok kebijakan moneter tersebut antara lain:

a. Kebijakan Pasar Terbuka (Open Market Operation) 
208 | Triwahyuni, Pengendalian Inflasi, Moneter dan Fiskal dalam Perspektif Ekonomi Makro Islam

Kebijakan ini merupakan kebijaka membeli atau menjual surat berharga atau obligasi dipasar terbuka. Apabila bank sentral ingin menambah supply uang, maka bank sentral akan membeli

b. Obligasi dan apabila sebaliknya bank sentral akan menurunkan jumlah uang yang beredar maka bank sentral akan menjual obligasi.

c. Penentuan Cadangan Wajib Minimum (Reserve Requirement)

Bank sentral umumnya menentukan angka rasio minimum antara uang tunai (reserve) dengan kewajiban giral bank (deman deposits) yang biasa disebut minimum legal reserve ratio. Apabila bank sentral menurunkan angka tersebut dengan uang tunai yang sama, maka bank dapat menciptakan uang dengan jumlah yang lebih banyak daripada sebelumnya.

d. Penentuan Suku Bunga Diskon (Discount Rate)

Bank sentral merupakan sumber dana bagi bank-bank umum atau komersial dan sebagai sumber dana yang terakhir. Bank komersial dapat meminjam dari bank sentral dengan tingkat suku bunga sedikit dibawah tingkat suku bunga kredit jangka pendek yang berlaku dipasar bebas. Discount rate yang bank sentral kenakan terhadap peminjam ke bank komersial mempengaruhi tingkat keuntungan bank komersial tersebut dan keinginan meminjam dari bank sentral. Ketika discount rate relatif rendah terhadap tingkat bunga pinjaman maka bank komersial akan mempunyai kecenderungan untuk meminjam dari bank sentral.

e. Moral Suasion

Kebijakan ini merupakan suatu kebijakan bank sentral yang bersifat persuasif berupa himbauan atau bujukan moral kepada bank.

\section{Dampak Pengendalian Inflasi Terhadap Perekonomian}

Dalam ekonomi Islam, antara sektor moneter dan sektor riil mestilah sejalan dan secara tegas moneter harus mengikuti perkembangan yang ada pada sektor riil (Karim, 2020). Sistem keuangan syariah di Indonesia mengalami pertumbuhan dan perkembangan yang sangat signifikan, hal ini dapat dilihat dari instrumen moneter syariah yang telah berkembang seiring dengan peningkatan kinerja dan tingkat kepercayaan masyarakat terhadap perbankan syariah. Terdapatnya peningkatan atas 
jumlah Dana Pihak Ketiga (DPK) sampai posisi Desember 2018 yaitu sebesar Rp 379.963 Miliar dan jumlah pembiayaan yang telah disalurkan sampai posisi Desember 2018 yaitu sebesar Rp 329.277 Miliar, serta adanya instrumen moneter berupa Pasar Uang Antar Bank Syariah (PUAS) dan Sertifikat Bank Indonesia Syariah (SBIS) untuk membantu likuiditas perbankan syariah pun (OJK, 2019).

Karakter keuangan syariah memperlihatkan adanya keterkaitan langsung antara sektor moneter dengan sektor riil. Sebagaimana dalam teori endogenous Islam perkembangan sektor moneter hanyalah representasi dari perubahan-perubahan dari sektor riil. Kebijakankebijakan baik itu moneter maupun fiskal dalam ekonomi Islam selalu berorientasi kepada pengalokasian sumber daya untuk mencapai produktivitas penuh dan paradigm ini juga berlaku dalam pengelolaan permintaan uang (Karim, 2017).

Dengan adanya peningkatan pada pembiayaan bank syariah yang ditujukan pada sektor riil akan berpengaruh pada jumlah barang dan jasa yang dihasilkan di masyarakat. Pemenuhan kebutuhan domestik kemungkinan besar akan terpenuhi pada saat produktivitas masyarakat meningkat dan pilihan untuk melakukan ekspor barang ke luar negeri akan meningkat pula. Terjadinya peningkatan angka ekspor maka akan menambah sumber pendapatan negara dari pendapatan devisa yang dihasilkan dan akan digunakan untuk memenuhi kebutuhan barang modal kebutuhan dalam negeri. Sebagaimana pendapatan Ibn Khaldun bahwa ketika suatu negara melakukan kegiatan ekspor maka kebutuhan domestik akan barang dan jasa sudah terpenuhi.

\section{SIMPULAN}

Kebijakan moneter merupakan instrumen penting kebijakan politik dalam sistem ekonomi, baik modern maupun Islam. Perbedaan yang mendasar terletak pada tujuan dan larangan bunga dalam Islam. Syarat tercapai dan terjamin berfungsinya sistem moneter secara baik adalah otoritas moneter harus melakukan pengawasan kepada keseluruhan sistem. Kebijakan moneter dan kebijakan fiskal merupakan kebijakan ekonomi makro yang sangat penting dalam kaitan dengan pencapaian target inflasi dan pertumbuhan ekonomi. Oleh karena dalam upaya mengatasi inflasi, kebijakan moneter dan fiskal, pemerintah dapat melakukan berbagai kebijakan ekonomi makro untuk 
210 | Triwahyuni, Pengendalian Inflasi, Moneter dan Fiskal dalam Perspektif Ekonomi Makro Islam mencapai target inflasi dan pertumbuhan ekonomi. Dengan demikian maka dapat ditegaskan pada bagian akhir ini bahwa demikian pentingnya peran pemerintah dan negara untuk mengambil berbagai kebijakan ekonomi dalam rangka mempertahankan stabilitas ekonomi sesuai dengan tantangan yang dihadapi saat ini dan di masa depan.

\section{DAFTAR PUSTAKA}

Aravik, Havis. (2017). Sejarah Pemikiran Ekonomi Islam Kontemporer, Jakarta: Kencana.

Asturi. Wulan, (2013). Pengaruh Instrumen Moneter Syariah dan Ekspor Terhadap Pertumbuhan Ekonomi di Indonesia, Jurnal Al-Iqtishad, Vol. V, No. 2 Edisi Juli 2013.

Bank Indonesia, Tujuan Kebijakan Moneter, artikel dalam https://www.bi.go.id/id/moneter/ tujuan-kebijakan/ Contents/Default.aspx

Bank Indonesia, Statistik Perbankan Syariah, artikel dalam https://www.ojk.go.id/id/kanal/ syariah/data-dan-statistik/statistik-perbankansyariah

Budiyanti, Eka. (2014). Pengaruh Kebijakan Moneter Terhadap Kinerja Sektor Industri Manufaktur di Indonesia, Jurnal Ekonomi dan Kebijakan Publik, Vol. 5 No. 2, Edisi Desember 2014.

Janwari. Yadi, (2016). Pemikiran Ekonomi Islam; Dari Masa Rasulullah Hingga Masa Kontemporer, Bandung: Rosda Karya.

Karim, Adiwarman. (2002). Ekonomi Islam Suatu Kajian Ekonomi Makro, Jakarta. The International Institute of Islamic Thought Indonesia. 